\section{Evaluation of Gamma-linolenic Acid Composition of Evening Primrose (Oenothera) Species Native to Texas}

\author{
S.A. Balch ${ }^{1}$, C.B. McKenney ${ }^{2}$, and D.L. Auld ${ }^{3}$ \\ Department of Plant and Soil Science, Texas Tech University, Lubbock, \\ TX 79409-2122
}

\section{Additional index words. evening primrose oil, GLA}

\begin{abstract}
The oil of evening primrose (Oenothera sp.) is an important source of gammalinolenic acid (GLA). GLA [C18:3 $16,9,12]$ is an unsaturated fatty acid in demand for its nutritional and pharmaceutical application. Oenothera biennis $\mathrm{L}$. is the primary commercial source of evening primrose oil. A study was conducted to determine if species of Oenothera, adapted to Texas, produce GLA levels comparable to $O$. biennis. This project identified and evaluated the fatty acid composition of eight species of evening primrose native to Texas. GLA levels of $\mathbf{5 4}$ accessions evaluated from collected seed ranged from $0.0 \%$ to $11.0 \%$. Field experiments were then conducted to determine oil content, fatty acid composition, seed yield, and potential adaptation to commercial production of selected accessions. Mean GLA levels of cultivated seed from these accessions ranged from $0.0 \%$ to $10.1 \%$. Mean seed oil content ranged from $7.3 \%$ to $21.7 \%$. Of the species examined, $O$. elata subsp. hirsutissima (A. Gray ex S. Watson) W. Dietrich and $O$. jamesii (Torrey \& Gray) demonstrated GLA levels and seed yields adequate for commercial production. Based on these results, $O$. elata subsp. hirsutissima and $O$. jamesii demonstrated sufficiently high GLA levels, oil content, and seed yields to be considered for commercial production.
\end{abstract}

In recent years, there has been increased interest in plants that produce gamma-linolenic acid (GLA). In humans and other mammals, GLA is an important intermediate in the conversion of linoleic acid to prostaglandins, thromboxanes, and other long-chain polyunsaturated fatty acids (Horrobin, 1992). This compound is considered an essential fatty acid, since, like vitamins, it cannot be synthesized by animals and must be consumed in the diet from plant sources (Lehninger, 1982). Prostaglandins and thromboxanes are hormone regulators which affect many cellular functions and regulate some blood platelet activities. The rate-determining step in the bioconversion of linoleic acid to arachidonic acid, the precursor of prostaglandins and thromboxanes, is believed to be the formation of the double bond at the $C-6$ carbon by the enzyme $\Delta 6$-desaturase (Horrobin, 1992). This enzyme catalyzes the conversion of linoleic acid to gamma-linolenic acid. Although most humans consume sufficient quantities of linoleic acid, it has been shown that certain factors such as stress, aging, diabetes, and alcohol consumption can inhibit or reduce the activity of the $\Delta 6$-desaturase enzyme (Horrobin, 1992; Phillips and Huang, 1996). In recent medical research, it has been found that dietary supplementation of GLAcan be effective in the treatment of these conditions (Carter, 1988).

Received for publication 13 Nov. 2001. Accepted for publication 23 Aug. 2002. Texas Tech Univ. Paper No. T-4-516. This research was funded in part by the Texas Dept. of Agriculture.

${ }^{1}$ Former Graduate Student.

${ }^{2}$ Assistant Professor.

${ }^{3}$ Professor.
Evening primrose (Oenothera biennis L.) was the first plant used for the isolation of GLA (Gunstone, 1992), and it is the primary source of GLA used in clinical and pharmaceutical applications (Phillips and Huang, 1996). GLA was extracted from the oil in the seeds of this plant. Hudson (1984) reported that evening primrose seed contains $24 \%$ oil with gammalinolenic acid comprising $7 \%$ to $14 \%$ of the fatty acid component. Evening primrose oil is available as a nutritional supplement in over 30 countries and Oenothera biennis is grown commercially in at least 15 countries (Carter, 1988). In 1988, Canada and the United States produced 300-400 tons of evening primrose seed. Most of the commercial production of evening primrose oil in North America is located in Canada and in the eastern United States (Brandle et al., 1993; Hall et al., 1988). These are areas of high rainfall and moderate temperatures. Little work has been done to evaluate the fatty acid composition of Oenothera species native to semiarid regions of the United States. A native evening primrose with commercial levels of GLA would have potential as a high-value oil crop in areas of high temperatures and low annual rainfall. The objectives of this project were to: 1) identify and collect species of evening primrose native to the western regions of Texas, 2) analyze the fatty acid composition of the seed oil of these species, and 3) evaluate their adaptability to commercial field production.

\section{Methods and Materials}

The collection area included the Northern High Plains and Southern High Plains, the Texas Rolling Plains, and the Edwards Plateau regions of Texas. In the spring and early summer, tagging trips were taken to locate evening primrose species while they were in bloom so that identification could be made. Voucher specimens were collected for each species of the study. Each collection site was recorded using a hand-held GeoExplorer global positioning unit. In the late summer or fall, plant populations were relocated and ripened seed capsules were collected. A threshing machine was used to break open capsules and separate seed from other plant debris. Seed was further cleaned with a seed blower (General Mfg.). Cleaned seed was stored in air-tight plastic containers in a refrigeration unit held at $4{ }^{\circ} \mathrm{C}$.

Seeds from each collection site were analyzed for fatty acid composition (Speed, 1995). A 300-mg sample of seed from each accession was used. Oil was extracted from the seed by grinding whole seeds in $20 \mathrm{~mL}$ of hexane using a Polytron grinder. The oil/hexane mixture was poured through a Whatman filter into 20$\mathrm{mL}$ scintillation vials. Vials were placed into a heating block at $50{ }^{\circ} \mathrm{C}$ and the hexane was evaporated with a continuous flow of nitrogen gas. Methyl esters of the oil were made by adding $1 \mathrm{~mL}$ of methylation mixture to each sample and inverting the capped sample for mixing. The methylation mixture was composed of $29.1 \mathrm{~mL}$ of $14 \%$ borontrifluoride in methanol, $20 \mathrm{~mL}$ of toluene, and $50.9 \mathrm{~mL}$ of methanol. Samples were placed in a heating block at $100^{\circ} \mathrm{C}$ for $20 \mathrm{~min}$. Samples were then removed from the heating block and allowed to cool for $10 \mathrm{~min}$. Each sample was rinsed with 2 $\mathrm{mL}$ of deionized water and $1 \mathrm{~mL}$ of hexane and shaken to mix well. The mixture was allowed to separate into two layers and the hexane layer was pipetted into vials for gas chromatograph analysis. Nitrogen gas was blown into each sample vial before it was capped to prevent oxidation of the sample.

Samples were analyzed using a Hewlett Packard 5890 Series II Gas Chromatograph equipped with a Supelco $30 \mathrm{~m} \times 0.53 \mathrm{~mm} \times$ $0.5 \mu \mathrm{m}$ fused silica capillary column and flame ionization detector (Speed, 1995). The initial oven temperature of $210^{\circ} \mathrm{C}$ was increased at the rate of $4{ }^{\circ} \mathrm{C}$ per minute until a final temperature of $240{ }^{\circ} \mathrm{C}$ was reached. The injector port was set at $200^{\circ} \mathrm{C}$ and the flame ionization detector was set at $250^{\circ} \mathrm{C}$. Output of the flame ionization detector was recorded on an HP3396 Series II Integrator. Fatty acid composition was calculated by summing the total area of all fatty acids detected and dividing each fatty acid by the total area. Peaks were identified by comparing retention times to reference standard retention peaks of known composition (Sigma AOCS No. 3, Sigma AOCS No. 5, Alltech Methyl Ester Standards).

Seeds harvested from cultivated plots were analyzed for percent oil at the Univ. of Idaho, using a Newport MKIIIA nuclear magnetic resonance instrument (Newport of North America, Villanova, Pa.). Analyses were made on oven-dried seed, using a canola standard of $36.2 \%$ oil.

Species with high levels GLA were evaluated in field studies in 1996, 1997, 1998, and 1999. Seeds were sown in a soilless mix in 
the greenhouse in January of each year and transplanted to the field in May. Plants were grown at the Erskine Research Farm in Lubbock, Tex., under drip irrigation. The soil at this site was an Amarillo fine sandy loam. Each species was planted in a completely randomized block design with four replicates. Seeds were harvested at maturity and threshed and analyzed for fatty acid composition using the above procedure.

Data were subjected to analysis of variance procedures (SAS Institute, 1998). Mean separations were performed using Fisher's Protected Least Significant Difference procedures at the $P \leq 0.05$ level.

\section{Results and Discussion}

From 1995 to 1997 , seed from 83 accessions of nine species of evening primrose were collected. The area surveyed included portions of the High Plains, the Rolling Plains, the Edwards Plateau, and the Crosstimbers and Prairies regions of Texas. Manual of the Vascular Plants of Texas (Correll and Johnston, 1970) and Systematic Botany Monographs Vol. 50 (Dietrich et al., 1997) were used to identify species.

Fatty acid composition of oil from native collected seed showed minimal differences among species in levels of palmitic, stearic, oleic, and linoleic acids (Table 1). Linoleic acid was the dominant fatty acid found in all species tested. This is in agreement with fatty acid composition of Oenothera reported by Gunstone (1992). Levels of GLA varied widely among species but were consistent within accessions of a species with the exception of several accessions of $O$. rhombipetala, which showed significant variation in GLA content, ranging from $1.5 \%$ to $6.8 \%$.

GLA levels of $11.0 \%$ were found in one accession (R50) of $O$. jamesii collected in 1997. The accession of $O$. elata collected in 1996 had a GLA level of 6.1\%. GLA levels of $O$. rhombipetala ranged from $1.2 \%$ in 1997 to $6.8 \%$ in 1996 and averaged $4.3 \%$ (four accessions) in 1996 and averaged $4.1 \%$ (five accessions) in 1998. GLA levels of O. speciosa ranged from $0.0 \%$ to $2.2 \%$ but averaged $1.7 \%$ in 1996 and $0.0 \%$ in 1997. All accessions of O. grandis, O. missouriensis, O. brachycarpa, and $O$. laciniata had GLA levels of $<0.5 \%$. Statistical analyses were not conducted on fatty acid composition of native collected seed due to the low numbers of accessions collected of some species. Accessions with high levels of GLA were included in subsequent field evaluations.

Each collected species was grown in the field for a minimum of 2 years. Species exhibiting $<2.0 \%$ GLA levels were not evaluated in subsequent years. Oenothera biennis was used as the control in 1996 and 1997 in field trials, but insect infestations limited its continued use as a control in 1998 and 1999. Oenothera elata was used as the control in 1998 and 1999 because it represented a better adapted check.

Selected accessions of Oenothera species were grown under cultivated conditions at Lubbock, Tex. In 1996, O. rhombipetala, $O$. grandis, and $O$. engelmannii were grown along with a commercial source of $O$. biennis. GLA levels of $O$. biennis were significantly higher than those of $O$. rhombipetala (Table 2). Levels of GLA in $O$. rhombipetala were significantly higher than those of $O$. grandis and O. engelmannii. In 1997, oil of O. elata with $10.1 \%$ GLA was significantly higher than O. biennis with $8.0 \%$. Oenothera biennis had significantly higher levels than O.rhombipetala with $6.3 \%$. Oenothera speciosa, O. grandis, and $O$. missouriensis had levels $<2.2 \%$, which severely limited their commercial potential. In 1998, O. jamesii with $9.1 \%$ and O. elata with $8.0 \%$ had significantly higher GLA levels than O. rhombipetala, which had $4.1 \%$. Oenothera speciosa contained the lowest amount of GLA (1.5\%). Again in 1999, O. jamesii and O. elata had GLA levels of over $8 \%$, which was significantly higher than $O$. rhombipetala at $3.6 \%$.

Oenothera elata, $O$. rhombipetala, and $O$. biennis had significantly higher GLA levels in 1997 than in other years (Table 2). Oenothera speciosa and $O$.jamesii showed no differences among years of this study.

Comparisons of fatty acid composition between native collected seed and cultivated seed of the same accessions of eight species showed a modest correlation in concentration of GLA levels $\left(r=0.73^{* *}, \mathrm{df}=12\right)$. Seeds from cultivated plants of $O$. jamesi $i$ had GLA levels ranging from $8.3 \%$ to $10.5 \%$ (data not shown) in 1998 and $6.8 \%$ to $10.7 \%$ in 1999 compared to the 1997 native collection with $11 \%$ and the 1998 native collection with $6.8 \%$. Oenothera jamesii was collected in a mesic habitat that may have greater water availability comparable to field conditions. In all three years of cultivation, Oenothera elata demonstrated greater GLA levels ( $8.0 \%$ to $10.1 \%$ ) than the original collected seed $(6.1 \%)$.

In 1999, seeds harvested from the upper (terminal) half of a branch, which matured in October, were compared to seeds harvested from the lower half of the branch in two species $O$. jamesii and O. elata. Comparisons of fatty acid composition showed that although there was a tendency toward higher GLA levels in the upper half of the branches, differences were not statistically significant (data not shown). Average GLAlevels of seed in the upper halves of O. elata and $O$.jamesi $i$ were $8.3 \%$ and $8.9 \%$, respectively, while those of the lower halves were $6.6 \%$ and $7.3 \%$.

In 1996, mean oil percentages of cultivated plants ranged from $10.8 \%$ to $17.3 \%$, with oil content of $O$.rhombipetala and O. engelmannii being significantly higher than $O$. biennis and O. grandis (Table 2). In 1997, oil content ranged from $11.1 \%$ to $19.3 \%$, with $O$. speciosa and $O$.rhombipetala having significantly higher oil content than O. biennis and O. grandis. In 1998, oil content ranged from $7.3 \%$ in $O$. elata to $20.7 \%$ in $O$. speciosa, which had significantly higher oil content than all others in that year. In 1999 , oil content ranged from $13.5 \%$ in $O$. rhombipetala to $18.6 \%$ in O. elata, which was significantly higher than $O$.jamesii $(17.3 \%$ ) and O. rhombipetala. It was interesting to note that over the 4-year period the two species with the highest average oil content (O. speciosa and O.engelmannii) were two species that had low GLA percentages. Oenothera elata, a species with consistently high GLA levels, had the lowest average oil content in 1998.

It has been reported that seeds maturing under cooler conditions generally produce more unsaturated fatty acids than under

Table 1. Average fatty acid composition of seed collected from nine species of evening primrose (Oenothera sp.) native to Texas in 1996,1997, and 1998.

\begin{tabular}{|c|c|c|c|c|c|c|c|c|}
\hline \multirow[b]{2}{*}{ Year } & \multirow[b]{2}{*}{ Species } & \multirow{2}{*}{$\begin{array}{c}\text { Access. } \\
\text { (no.) }\end{array}$} & \multicolumn{6}{|c|}{ Fatty acid composition } \\
\hline & & & $\mathrm{C} 16: 0$ & C18:0 & C18:1 & $\mathrm{C} 18: 2$ & $\gamma \mathrm{C} 18: 3$ & $\alpha \mathrm{C} 18: 3$ \\
\hline \multirow{7}{*}{1996} & & & - & - & $-\%$ methyl e & td error)---- & ------------ & ------------ \\
\hline & O. engelmannii & 7 & $9.4( \pm 0.4)$ & $0.8( \pm 0.2)$ & $10.1( \pm 0.8)$ & $71.0( \pm 4.6)$ & 0.0 & 0.0 \\
\hline & O. grandis & 4 & $9.3( \pm 0.4)$ & $1.0( \pm 0.2)$ & $9.8( \pm 0.9)$ & $74.7( \pm 2.3)$ & 0.0 & 0.0 \\
\hline & O. missouriensis & 3 & $7.5( \pm 0.5)$ & $1.1( \pm 0.3)$ & $13.2( \pm 0.4)$ & $75.3( \pm 0.7)$ & 0.0 & 0.0 \\
\hline & O. rhombipetala & 4 & $7.8( \pm 0.3)$ & $2.0( \pm 0.0)$ & $9.2( \pm 0.9)$ & $72.2( \pm 2.1)$ & $4.3( \pm 1.1)$ & $0.1( \pm 0.1)$ \\
\hline & O. speciosa & 3 & $10.1( \pm 0.5)$ & $2.3( \pm 0.1)$ & $12.2( \pm 0.3)$ & $66.8( \pm 4.7)$ & $1.7( \pm 0.3)$ & $0.1( \pm 0.0)$ \\
\hline & O. elata & 1 & 6.3 & 1.6 & 10.1 & 72.4 & 6.1 & 0.0 \\
\hline \multirow[t]{7}{*}{1997} & O. engelmannii & 3 & $9.4( \pm 0.6)$ & $1.0( \pm 0.3)$ & $7.8( \pm 0.4)$ & $74.3( \pm 2.1)$ & 0.0 & 0.0 \\
\hline & O. missouriensis & 8 & $8.5( \pm 0.3)$ & $1.4( \pm 0.2)$ & $12.2( \pm 0.9)$ & $68.3( \pm 1.5)$ & 0.0 & 0.0 \\
\hline & O. rhombipetala & 1 & 7.8 & 2.1 & 8.6 & 73.4 & 1.2 & 0.1 \\
\hline & O. speciosa & 4 & $12.6( \pm 0.2)$ & $2.3( \pm 0.2)$ & $10.5( \pm 0.8)$ & $64.5( \pm 3.0)$ & 0.0 & 0.0 \\
\hline & O. brachycarpa & 2 & $8.6( \pm 0.2)$ & $2.2( \pm 0.1)$ & $12.9( \pm 1.3)$ & $68.6( \pm 0.1)$ & 0.0 & 0.0 \\
\hline & O.jamesii & 1 & 8.2 & 1.4 & 11.7 & 58.6 & 11.0 & 0.0 \\
\hline & O. laciniata & 2 & $10.3( \pm 0.1)$ & $1.7( \pm 0.2)$ & $7.2( \pm 0.6)$ & $70.0( \pm 0.5)$ & 0.0 & 0.0 \\
\hline \multirow[t]{2}{*}{1998} & O. rhombipetala & 5 & $8.6( \pm 0.2)$ & $1.6( \pm 0.3)$ & $10.0( \pm 0.4)$ & $65.1( \pm 0.9)$ & $4.1( \pm 1.4)$ & 0.0 \\
\hline & O. jamesii & 1 & 7.6 & 1.5 & 13.5 & 60.5 & 6.8 & 0.0 \\
\hline
\end{tabular}


Table 2. Average fatty acid composition and percent oil content of 10 accessions of Oenothera species grown at Lubbock, Tex., in 1996, 1997, 1998, and 1999.

\begin{tabular}{|c|c|c|c|c|c|c|c|c|c|}
\hline \multirow[b]{2}{*}{ Year } & \multirow[b]{2}{*}{ Species } & \multirow[b]{2}{*}{ Access. } & \multicolumn{6}{|c|}{ Fatty acid composition ${ }^{z}$} & \multirow{2}{*}{$\begin{array}{c}\text { Oil } \\
\text { content }\end{array}$} \\
\hline & & & C16:0 & C18:0 & $\mathrm{C} 18: 1$ & $\mathrm{C} 18: 2$ & $\gamma \mathrm{C} 18: 3$ & $\alpha \mathrm{C} 18: 3$ & \\
\hline \multirow{5}{*}{1996} & & & & & $------\%$ & yl ester - & & & $---\%---$ \\
\hline & O. biennis & P118 & $6.9 \mathrm{a}^{\mathrm{y}}$ & $1.5 \mathrm{~b}^{\mathrm{y}}$ & $21.5 \mathrm{a}^{\mathrm{y}}$ & $63.2 b^{y}$ & $6.2 \mathrm{a}^{\mathrm{y}}$ & $0.1 \mathrm{a}^{\mathrm{y}}$ & $10.8 b^{y}$ \\
\hline & O. rhombipetala & P113 & $8.1 \mathrm{a}$ & $2.0 \mathrm{a}$ & $8.5 \mathrm{~b}$ & $74.1 \mathrm{a}$ & $4.0 \mathrm{~b}$ & $0.1 \mathrm{a}$ & $17.3 \mathrm{a}$ \\
\hline & O. grandis & P7 & $7.7 \mathrm{a}$ & $2.0 \mathrm{a}$ & $10.4 \mathrm{~b}$ & $76.7 \mathrm{a}$ & $0.1 \mathrm{c}$ & $0.1 \mathrm{a}$ & $13.4 \mathrm{~b}$ \\
\hline & O. engelmannii & P95 & $7.5 \mathrm{a}$ & $1.5 \mathrm{~b}$ & $8.2 \mathrm{~b}$ & $76.4 \mathrm{a}$ & $0.0 \mathrm{c}$ & $0.1 \mathrm{a}$ & $18.0 \mathrm{a}$ \\
\hline \multirow[t]{6}{*}{1997} & O. elata & $\mathrm{R} 50$ & $7.2 \mathrm{bcd}^{y}$ & $1.5 \mathrm{c}^{\mathrm{y}}$ & $7.3 \mathrm{~d}^{y}$ & $67.0 \mathrm{~b}^{\mathrm{y}}$ & $10.1 \mathrm{a}^{\mathrm{y}}$ & $0.3 \mathrm{a}^{\mathrm{y}}$ & $14.6 b c^{y}$ \\
\hline & O. biennis & P118 & $6.8 \mathrm{~cd}$ & $1.5 \mathrm{c}$ & $17.5 \mathrm{a}$ & $60.0 \mathrm{c}$ & $8.0 \mathrm{~b}$ & $0.2 \mathrm{a}$ & $12.5 \mathrm{c}$ \\
\hline & O. rhombipetala & R46 & $7.6 \mathrm{bc}$ & $1.9 \mathrm{~b}$ & $7.9 \mathrm{~cd}$ & $69.3 \mathrm{~b}$ & $6.3 \mathrm{c}$ & $0.1 \mathrm{a}$ & $16.5 \mathrm{ab}$ \\
\hline & O. speciosa & R36 & $9.6 \mathrm{a}$ & $2.6 \mathrm{a}$ & $12.1 \mathrm{~b}$ & $66.6 \mathrm{~b}$ & $2.2 \mathrm{~d}$ & $0.3 \mathrm{a}$ & $19.3 \mathrm{a}$ \\
\hline & O. grandis & R1 & $7.3 \mathrm{bcd}$ & $1.9 \mathrm{~b}$ & $9.7 \mathrm{c}$ & $70.7 \mathrm{ab}$ & $1.8 \mathrm{~d}$ & $0.0 \mathrm{a}$ & $11.1 \mathrm{c}$ \\
\hline & O. missouriensis & $\mathrm{R} 21$ & $6.7 \mathrm{~d}$ & $1.5 \mathrm{c}$ & $14.1 \mathrm{~b}$ & $68.1 \mathrm{~b}$ & $0.0 \mathrm{e}$ & $0.3 \mathrm{a}$ & $13.6 \mathrm{bc}$ \\
\hline \multirow[t]{4}{*}{1998} & O. jamesii & T60 & $9.6 b^{y}$ & $1.5 b^{y}$ & $6.8 \mathrm{~b}^{\mathrm{y}}$ & $62.5 b^{y}$ & $9.1 \mathrm{a}^{\mathrm{y}}$ & $0.3 \mathrm{~b}^{\mathrm{y}}$ & $12.8 \mathrm{~b}^{\mathrm{y}}$ \\
\hline & O. elata & R50 & $11.1 \mathrm{a}$ & $2.2 \mathrm{a}$ & $7.0 \mathrm{~b}$ & $52.5 \mathrm{c}$ & $8.0 \mathrm{a}$ & $0.5 \mathrm{a}$ & $7.3 \mathrm{c}$ \\
\hline & O. rhombipetala & R46 & $7.1 \mathrm{c}$ & $2.1 \mathrm{a}$ & $6.9 \mathrm{~b}$ & $73.9 \mathrm{a}$ & $4.4 \mathrm{~b}$ & $0.2 b c$ & $14.2 \mathrm{~b}$ \\
\hline & O. speciosa & R36 & $10.5 \mathrm{ab}$ & $2.4 \mathrm{a}$ & $11.1 \mathrm{a}$ & $65.4 \mathrm{~b}$ & $1.5 \mathrm{c}$ & $0.1 \mathrm{c}$ & $20.7 \mathrm{a}$ \\
\hline \multirow[t]{3}{*}{1999} & O. jamesii & T60 & $7.2 \mathrm{a}^{\mathrm{y}}$ & $1.6 \mathrm{~b}^{\mathrm{y}}$ & $9.1 \mathrm{a}^{y}$ & $68.6 \mathrm{a}^{y}$ & $8.9 \mathrm{a}^{\mathrm{y}}$ & $0.1 \mathrm{~b}^{\mathrm{y}}$ & $17.3 b^{y}$ \\
\hline & O. elata & R50 & $7.5 \mathrm{a}$ & $1.8 \mathrm{~b}$ & $7.4 \mathrm{a}$ & $63.8 \mathrm{a}$ & $8.3 \mathrm{a}$ & $0.1 \mathrm{~b}$ & $18.6 \mathrm{a}$ \\
\hline & O. rhombipetala & R46 & $7.6 \mathrm{a}$ & $2.2 \mathrm{a}$ & $8.5 \mathrm{a}$ & $63.5 \mathrm{a}$ & $3.6 \mathrm{~b}$ & $2.3 \mathrm{a}$ & $13.5 \mathrm{c}$ \\
\hline
\end{tabular}

${ }^{2}$ Composition reported for six major fatty acids: C16:0, palmitic acid; C18:0, stearic acid; C18:1, oleic acid; C18:2, linoleic acid; $\gamma$ C18:3, gamma-linolenic acid; $\alpha \mathrm{C} 18: 3$, alpha-linolenic acid.

${ }^{y}$ Means within a year and a column not followed by the same letter differ at the 0.05 level by Fisher's Protected Least Significant Difference Test.

warmer conditions (Bewley and Black, 1994). Canvin (1965) reported that oil of sunflower had high linoleic acid and low oleic acid under low temperatures, and oil of flax had decreased linoleic and linolenic acid percentages under higher temperatures. He found that fatty acid composition was not affected by temperature in the oil of castor and safflower. Yaniv and Perl (1987) demonstrated that the sum of linoleic acid and linolenic acid fractions decreased with increasing temperature in $O$. biennis and $O$. lamarkiana. Of all the species evaluated in these trials, the two producing oil containing the highest GLAlevels (O. elata and O.jamesii) bloomed in the fall and had seed maturing in October and November when night temperatures were cooler. This could be an important factor determining which species of Oenothera produce oils containing high levels of GLA.

Seed yields in 1996, calculated on a per plant basis, showed $O$. biennis with an average $22.6 \mathrm{~g}$ per plant $\left(363 \mathrm{~kg} \cdot \mathrm{ha}^{-1}\right)$ and $O$. rhombipetala with $22.9 \mathrm{~g}$ per plant $\left(369 \mathrm{~kg} \cdot \mathrm{ha}^{-1}\right)$ had significantly higher yields than $O$. grandis, $O$. englemannii, and $O$. missouriensis, which produced less than $3.0 \mathrm{~g}$ per plant $\left(48 \mathrm{~kg} \cdot \mathrm{ha}^{-1}\right)$ (Table 3). In 1997, O. elata produced an average of $47.6 \mathrm{~g}$ of seed per plant $\left(766 \mathrm{~kg} \cdot \mathrm{ha}^{-1}\right)$, which was significantly higher than $O$. biennis with $27.5 \mathrm{~g}$ per plant $\left(443 \mathrm{~kg} \cdot \mathrm{ha}^{-1}\right)$. Oenothera rhombipetala seed yields of $9.1 \mathrm{~g}$ per plant (147 $\mathrm{kg} \cdot \mathrm{ha}^{-1}$ ) were less than half of 1996 seed yields and were significantly less than $O$. biennis. In 1999, O. elata had the highest seed yields of any species in any year with an average of $78.5 \mathrm{~g}$ per plant $\left(1264 \mathrm{~kg} \cdot \mathrm{ha}^{-1}\right)$. Seed yields of $O$. jamesii, $31.6 \mathrm{~g}$ per plant $\left(508 \mathrm{~kg} \cdot \mathrm{ha}^{-1}\right)$, were significantly less than $O$. elata but significantly more than $O$. rhombipetala, whose seed yields were less than half of what they had been in 1997. Seed yield data for 1998 was not included because of problems with threshing equipment. All plantings were at 60 $\mathrm{cm}$ spacing. In a field study comparing seed yield of three different plant spacings in three species of Oenothera (O. elata, O. jamesii,

Table 3. Seed yield of eight species of cultivated Oenothera grown at Lubbock, Tex., in 1996, 1997, and 1999.

\begin{tabular}{llccc}
\hline \multirow{2}{*}{ Year } & \multicolumn{1}{c}{$\begin{array}{c}\text { No. of } \\
\text { Species }\end{array}$} & \multicolumn{2}{c}{ Seed yield per plant } \\
\cline { 3 - 5 } 1996 & accessions & Avg & Range \\
\hline \multirow{4}{*}{1997} & O. biennis & 1 & $22.6 \mathrm{a}^{\mathrm{z}}$ & $10.2-53.2$ \\
& O. rhombipetala & 1 & $22.9 \mathrm{a}$ & $16.3-31.4$ \\
& O. grandis & 3 & $2.7 \mathrm{~b}$ & $0.3-4.3$ \\
& O. englemannii & 4 & $1.3 \mathrm{~b}$ & $0.1-2.6$ \\
& O. missouriensis & 1 & $0.2 \mathrm{~b}$ & $0.1-0.3$ \\
& O. elata & 1 & $47.6 \mathrm{a}^{\mathrm{z}}$ & $26.6-71.3$ \\
& O. biennis & 1 & $27.5 \mathrm{~b}$ & $16.3-35.9$ \\
& O. rhombipetala & 9 & $9.1 \mathrm{c}$ & $0.6-16.1$ \\
& O. missouriensis & 4 & $5.7 \mathrm{~cd}$ & $1.0-14.9$ \\
& O. grandis & 3 & $4.2 \mathrm{~cd}$ & $2.1-6.4$ \\
& O. englemannii & 4 & $3.6 \mathrm{de}$ & $1.1-13.0$ \\
& O. speciosa & 8 & $1.6 \mathrm{e}$ & $0.3-3.8$ \\
& O. elata & 1 & $78.5 \mathrm{a}^{\mathrm{z}}$ & $51.4-130.2$ \\
& O. jamesii & 1 & $31.6 \mathrm{~b}$ & $15.5-56.3$ \\
& O. rhombipetala & 1 & $3.8 \mathrm{c}$ & $1.2-7.7$ \\
\hline
\end{tabular}

${ }^{2}$ Means within a year and column not followed by the same letter differ at the 0.05 level by Fisher's Protected Least Significant Difference Test.

and $O$. rhombipetala), Murphy (2000) found that a $30 \mathrm{~cm}$ plant spacing gave the highest yield for all species evaluated, but only in $O$. jamesii was the $30 \mathrm{~cm}$ spacing significantly higher than $60 \mathrm{~cm}$ plant spacing.

Plants of O. elata, O.jamesii, and O.rhombipetala had an upright growth habit with cylindrical seed capsules held erect. As the seed capsules matured, shattering became an issue, but the erect seed capsules prevented excessive seed loss. These characteristics would be beneficial to mechanical harvesting with commercial combines. Plants of $O$. grandis and $O$. missouriensis had a prostrate growth habit, which would be nonconducive to mechanical harvesting. Oenothera engelmannii had stout seed capsules that were difficult to thresh. The accessions of $O$. grandis, $O$. missouriensis, $O$. engelmannii, and $O$. speciosa did not produce adequate seed yields to be commercially acceptable for an oilseed crop.

This study identified and evaluated nine species of Oenothera native to Texas for fatty acid composition, oil content, and seed yields. Of these nine species, O. elata and $O$. jamesi had high GLAlevels, sufficient oil content, and acceptable seed yields to be considered as potential candidates for commercial production. Native species showed little insect damage, whereas the non-native $O$. biennis was susceptible to insect damage. It has been reported that seed yields, oil content, and GLA levels are affected by precipitation and temperature during flowering and seed set (Brandle et al., 1993). Since O. elata and O.jamesii are found growing in mesic sites along riverbanks, these species may have potential as crops to be grown in Canada and the northeastern U.S., although the late-maturing seed may be limited by the length of the growing season. These two high GLA producing species demonstrated good seed production and showed promise as a potentially valuable crop for the nutritional and pharmaceutical industry. 


\section{Literature Cited}

Bewley, J. D. and M. Black. 1994. Seeds: Physiology of development and germination. $2^{\text {nd }}$ ed. Plenum Press, New York.

Brandle, J.E., W.A. Court, and R.C. Roy. 1993. Heritability of seed yield, oil concentration and oil quality among wild biotypes of Ontario evening primrose. Can. J. Plant Sci. 73:1067-1070.

Canvin, D.T. 1965. The effect of temperature on the oil content and fatty acid composition of the oils from several oil seed crops. Can. J. Bot. 43:63-69.

Carter, J.P. 1988. Gamma-linolenic acid as a nutrient. Food Technol. June.

Correll, D.S. and M.C. Johnston. 1970. Manual of the vascular plants of Texas. Texas Res. Foundation, Renner, Tex.
Dietrich, W., W.L. Wagner, and P.H. Raven. 1997. Systematics of Oenothera Section Oenothera subsection Oenothera (Onagraceae). Syst. Bot. Monogr. v. 50. Amer. Soc. Plant Taxon.

Gunstone, F.D. 1992. Gamma linolenic acid-Occurrence and physical and chemical properties. Prog. Lipid Res. 32(2):145-161.

Hall, I.V., E. Steiner, P. Threadgill, and R.W. Jones. 1988. The biology of Canadian weeds. Can. J. Plant Sci. 68:163-173.

Horrobin, D.F. 1992. Nutritional and medical importance of gamma-linolenic acid. Prog. Lipid Res. 31(2):163-194.

Hudson, B.J.F., 1984. Evening primrose (Oenothera spp.) oil and seed. J.Amer. Oil Chem. Soc. 61(3): 540-543.

Lehninger, A.L. 1982. Principles of biochemistry. Worth Publishers, New York.
Murphy, C.L. 2000. Field study of Texas native evening primrose and evaluation of selected seed treatments. MS Thesis, Dept. of Plant Soil Sci., Texas Tech Univ., Lubbock, Tex.

Phillips, J.C. and Y.-S. Huang. 1996. Natural sources and biosynthesis of $\gamma$-linolenic acid: An overview. In: Y. Huang and D. E. Mills (eds.). 1996. $\gamma$-Linolenic acid: Metabolism and its roles in nutrition and medicine. AOCS Press. Champaign, Ill.

Speed, T.R. 1995. Genetic and environmental influences on cold tolerance of cotton seedling germination. MS Thesis, Dept. of Plant \& Soil Sci., Texas Tech Univ., Lubbock, Tex.

Yaniv, Z. and M. Perl. 1987. The effect of temperature on the fatty acid composition of evening primrose (Oenothera) seeds during their development, storage and germination. Acta Hort. 215:31-38 